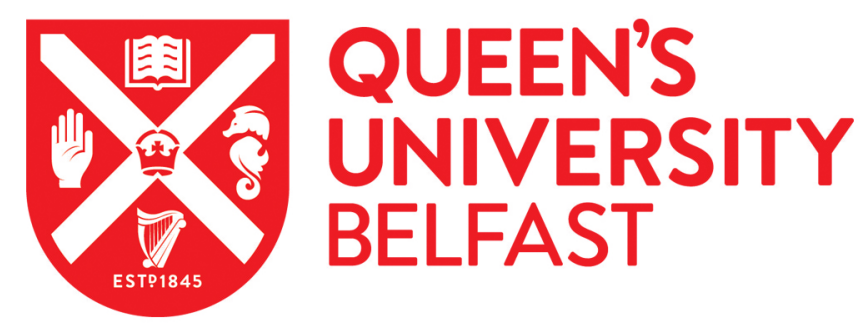

\title{
Incubation or Induction? Gendered Identity Work in the Context of Technology Business Incubation
}

Marlow, S., \& McAdam, M. (2015). Incubation or Induction? Gendered Identity Work in the Context of Technology Business Incubation. Entrepreneurship Theory and Practice, 39(4), 791-816.

https://doi.org/10.1111/etap.12062

Published in:

Entrepreneurship Theory and Practice

Document Version:

Peer reviewed version

Queen's University Belfast - Research Portal:

Link to publication record in Queen's University Belfast Research Portal

\section{Publisher rights}

Copyright 2013 Baylor University

This is the peer reviewed version of the following article:

Marlow, S. and McAdam, M. (2013), Incubation or Induction? Gendered Identity Work in the Context of Technology Business Incubation.

Entrepreneurship Theory and Practice, which has been published in final form at DOI: 10.1111/etap.12062

\section{General rights}

Copyright for the publications made accessible via the Queen's University Belfast Research Portal is retained by the author(s) and / or other copyright owners and it is a condition of accessing these publications that users recognise and abide by the legal requirements associated with these rights.

Take down policy

The Research Portal is Queen's institutional repository that provides access to Queen's research output. Every effort has been made to ensure that content in the Research Portal does not infringe any person's rights, or applicable UK laws. If you discover content in the Research Portal that you believe breaches copyright or violates any law, please contact openaccess@qub.ac.uk. 


\title{
Incubation or Induction? Gendered identity work in the context of technology business incubation
}

\begin{abstract}
Whilst there is a substantial body of literature which seeks to establish, or dispute, the beneficial influence of business incubation, this debate remains almost entirely gender blind. This article challenges this assumption by adopting a feminist perspective to reveal business incubation to be a gendered process which shapes the identity work undertaken by women seeking legitimacy as technology venturers. In so doing, we critically evaluate prevailing normative analyses of the business incubation process and entrepreneurial legitimation. To illustrate this argument, we draw upon empirical evidence which reveals technology incubation as a legitimating induction process encouraging women to reproduce masculinised representations of the normative technology entrepreneur.
\end{abstract}

Key Words: Entrepreneurship; gender; identity work; technology; legitimacy; business incubation.

\section{Introduction}

Since the early 1980s, there has been a growing critique of corporate/welfare capitalism as a sustainable socio-economic model for growth and innovation within advanced economies with an increasing emphasis upon individualism, de-regulation and entrepreneurship (Beck, 1992; Giddens, 1992; Ogbor, 2000). Consequently, a profoundly changed perception of the value and contribution of entrepreneurial activity to economic prosperity and individualised social aspiration has emerged (Smith and Anderson, 2004; Radu and Redien-Collot, 2008). Implicit within this thesis, entrepreneurship is represented as an accessible site of neutral socio-economic opportunity creation/effecting activity imbued with emancipatory potential (Rindova, et al., 2009). Contemporary analyses however, question this notion arguing that entrepreneurship is embedded within prevailing institutional biases (Calàs et al., 2009; Ahl and Marlow, 2012) which produce and reproduce bounded constraints regarding who can claim entrepreneurial legitimacy. To critically evaluate such arguments, we draw upon notions of gender, legitimacy and entrepreneurship. Accordingly, our key research question focuses upon an exploration of the reflexive identity work undertaken by women to gain legitimacy as credible entrepreneurs within the masculinised environment of high technology business incubators.

Exploring this research question enables us to offer critical contributions to current debate; first, we adopt a gendered stance to add theoretical depth to contemporary conceptualisations of entrepreneurial legitimacy through an exploration of the influence of incubation as a process and space which encourages particularised identity work prioritising the masculine. The extant literature generically describes incubation as a support initiative that provides bespoke premises and professional business advice to early stage entrepreneurs (Patton, 2013). The underlying assumption being that the proffered advice and the physical environment are benign and neutral with an unbiased objective to grow the business from concept to commercial viability. Prioritising the business as the unit of analysis and so failing to acknowledge the owner, and their related characteristics, as the physical embodiment of the new venture effectively masks the partiality within the incubation process 
and so, reproduces a biased ideal type of entrepreneurial legitimacy. Second, in developing these arguments, we strengthen the conceptual critique regarding the persistent but dynamic gender bias evident in mainstream theorising within entrepreneurship (Ahl, 2006; Neergaard et al., 2011; Hughes, 2012) illustrating this analysis using the context of business incubation.

To develop these arguments, we commence by outlining the rationale for our theoretical framework followed by a discrete analysis of the key constructs - gender, identity work and legitimacy in the context of entrepreneurship. We then draw these concepts together under the umbrella of incubated technology entrepreneurship which forms the basis of our empirical illustration of the analysis. The following section presents our methodological rationale and method; this is followed by critical evaluation of case study findings. Finally, we consider the implications of our arguments to advance theoretical insight into legitimating identity work enacted at the interface of gendered ascription and technological venturing.

\section{Theoretical framing}

Within this article, we consider identity work as an activity which reflexive subjects undertake in the attempt to be deemed legitimate within the various environments they encounter. However, as Ibarra (1999) observes, identity work is dynamic and iterative so it is enacted within situated contexts and shaped by the characteristics of those involved. Seeking and claiming legitimacy pivots upon successful identity work as only by convincing the dominant referent group of ' $\mathrm{fit}^{\prime}$ ' can the individual be deemed credible (Ibarra and Barbulescu, 2010; Wry et al., 2011). We transpose these notions to the field of entrepreneurship and in addition, introduce gender to this framework. For women, claiming entrepreneurial legitimacy is particularly challenging given the ethos of masculinity which informs this discourse and the associated identity work this prompts (MacNabb, 1993; Bruni et al., 2004; Ahl and Marlow, 2012). Thus, using identity work as a conceptual bridge between legitimacy, gender and entrepreneurship in the context of business incubation exposes how masculinity becomes an element of the 'doing' required for women to be recognised as credible technology venturers.

\section{Identity work}

Human actors have complex identities comprising elements of core personalities reflexively articulated through and within various social contexts; as such, identities are on-going projects arising from dialogues between an inner self and an external discourse reflecting the social domain (Sveningsson and Alvesson, 2003; Kenny, 2010). The production and reproduction of identity via this process requires individuals to engage in identity work informing the construction of credible subject positions within normative social contexts. Accordingly, identity work is conceptualised here as the mutually constitutive processes whereby people strive to shape a relatively coherent and distinctive notion of personal selfidentity and strive to shape the various social identities that emerge in relationship to others in the various milieux in which they live their lives' (Watson, 2009: 257). This refutes any notion of a de-contextualised static iteration of 'one' identity but rather, suggests a process of reflexive socially situated performances (Watson, 2009; Ibarra and Barbulescu, 2010). As such, an individual's evaluation of their own and the identities of others is socially situated and shaped by a desire for affirmation as a legitimate subject (Suls et al., 2002; Butler, 2004). Consequently, a key element of identity work is creating a sense of belongingness which in turn, enhances self-confirmation (Hogg, 2006). However, such identity work is constrained 
and channelled by the options available to an institutionally bounded subject position (Butler, 2004; Ybema, 2009).

Accordingly, the 'inner self' is not an autonomously owned space to which we can attach preferred identities but rather, is embedded within culture and context which defines socially prescribed subject positions (Butler, 1993). So, as reflexive actors, humans undertake dedicated identity work developing and testing probable and possible selves to demonstrate degrees of fit with a desired reference group (Ibarra, 1999: Ibarra and Barbulescu, 2010; Watson, 2013). Analyses of contemporary identity work have broadly revolved around the tension between the individual and the culture, norms and hierarchies embedded within the architecture of formal organisations (Ybema, 2009). Transposing this analysis to entrepreneurship is challenging given the agentic nature of the entrepreneurial process and the associated absence of normative institutionalised exemplars to inform related identity work (Down, 2006). As Watson (2013) argues, the sense of an archetypal entrepreneur identity is difficult to capture. It has morphed through shifting popularised scenarios from the 'spiv' (petty criminal) of the post war (1945+) period to more recently, the 'hero'- whose willingness to engage with the risks entailed in new venture creation results in employment and wealth generation (Radu and Redien-Collot, 2008). Consequently, exploring entrepreneurial identity work is challenging given the evident heterogeneity amongst those included within this sector and in the absence of normative guidelines and identity cues. As De Clerq and Voronov, (2009) note, this requires the individual to both stand out (through a novel offering) and fit in (so be recognisable as a credible entrepreneur).

Critiques of the debate regarding entrepreneurial identity however, have drawn attention to the gender blind assumptions informing this analysis (Bruni, et al., 2004; Ahl and Marlow, 2012) suggesting that the normative entrepreneur is assumed to be 'essentially more masculine than feminine, more heroic than cowardly' (Collins and Moore, 1964: 5). Accordingly, the ideal type embedded within current notions of the entrepreneurial identity reflects a male prototype as generic suggesting that normative constructions of femininity do not fit well with the historical or contemporary iterations of entrepreneurial identity (Essers and Benschop, 2009; Díaz García and Welter, 2013). This poses particular challenges to women; they must reach into a social space which is fundamentally unsympathetic to their gendered characterisation. Such assumptions have informed a feminist response with a growing literature exposing the masculine bias and associated stereotypes regarding the normative entrepreneurial discourse and the associated identity work this invokes (MacNabb, et al., 1993; Ahl, 2006; Benschop and Essers, 2009; McAdam, 2012). Within this dialogue, women have emerged as a cipher for gender; as Kelan (2009) notes, gender sticks to women given their designation as 'other'. As such, masculinity is taken as the default so is not considered a gender problem. Thus, in undertaking the identity work necessary to fit with entrepreneurial representation, women are obliged to do gender when, as Bruni et al., (2005) note, they 'oscillate' between symbolic spaces of masculinity and femininity.

Yet, the analytical focus upon the female as the substantive articulation of the construct of gender within the entrepreneurial field is in danger of presenting a universal reading of the tensions arising from women's designation as other. To address this issue, we need an active situated analysis of the identity work women perform within the differing entrepreneurial contexts they encounter to enact possible and provisional selves (Ibarra, 1999). As such, 
fitting in requires an iterative dialogue between new entrants to the field and present incumbents which is sensitive to prevailing and particularised norms. For women this involves reflexive identity work to retain and articulate femininity to preserve their social viability (Butler, 2004) but also, they have to recognise, translate and adopt various and diverse aspects of masculinity to be recognised as an entrepreneurial actor. So, within particular entrepreneurial contexts, gaining legitimacy requires identity work which interprets and balances masculinity and femininity to create provisional selves that fit within specific environments (Ibbara and Barbulescu, 2010). For example, those women creating new ventures in traditionally feminised sectors can draw upon assumptions which map competencies onto stereotypes. However, for those who enter male dominated industries, gender dissonance is exaggerated adding an additional dimension to the identity work required to seek and claim entrepreneurial legitimacy.

\section{Gender and entrepreneurial legitimacy}

Women are obliged to negotiate the dissonance between their ascribed femininity and the masculinity inherent within entrepreneurship. Indeed, at the most elementary level women are specifically coded by sex in that they are designated as female entrepreneurs within popular, policy and academic literatures (Ahl and Marlow, 2012). This differentiates them from the normative population of, what can only be assumed to be male entrepreneurs. Accordingly, we argue that women are obliged to undertake particular forms of identity work to achieve visibility and entrepreneurial legitimacy particularly when founding new ventures in traditionally male dominated sectors.

Attaining legitimacy requires contextualised recognition and approval for the self as a credible subject within a particular setting or across a cultural and symbolic milieu. Lounsboury and Glynn (2001: 546) refer to legitimation as a process of 'cultural alignment' whereby social actors attain and enact various credentials and behaviours from which they gain recognition as comprehensible field members. Legitimation emerges as a dialectic process premised upon the interface between possession of specific competencies articulated through dedicated identity work to generate appropriately displayed behaviours (Sillince and Barker, 2012). As such, legitimation is a power relationship whereby existing group members reproduce dominant norms but equally, there is space for challenge and change at the boundaries as new members gain acceptance and this in turn, ensures degrees of dynamism and so, refutes trends towards inevitable isomorphism.

However, as has been observed (Lounsbury and Glynn, 2001; Tornikoski and Newbert, 2006; Gartner, 2010; Cornelissen et al., 2012) the process of entrepreneurial legitimation presents particular difficulties for new entrants. As De Clercq and Voronov (2009: 395) observe, this legitimacy dilemma can best be described as attempts to 'fit in whilst standing out'. In effect, the credibility of aspiring entrepreneurs rests upon their ability to demonstrate additionality whilst reassuring resource gatekeepers (investors, advisors, suppliers, customers) of alignment with existing normative expectations. It is essential that this diverse group of gatekeepers can be persuaded to recognise entrepreneurial claimants as legitimate to enable the business to be founded and survive (Tornikoski and Newbert, 2006). Legitimating identity work in this context is challenging given the conflict between demonstrating novelty but also, field affiliation such that the new entrant 'makes sense' to existing stakeholders (Cornelissen et al., 2012) As such, there is considerable tension between the notion of the entrepreneur 
as an agentic change agent whose legitimacy rests upon novelty and the ability to signal competency on the basis of an existing track record of relevant skills and achievements.

Contributing to the difficulty of entrepreneurial legitimacy is the conflation of the individual and the enterprise. By definition, new firms lack legitimating track records; accordingly, the owner becomes the physical and metaphorical embodiment of the envisaged future firm (Storey and Greene, 2010). Thus, as Wry et al., (2011) argue, the potential of the business, which exists only in the imagination of the owner(s), must be convincingly conveyed to resource gatekeepers to ensure they share this vision. Unfolding a convincing story is, in effect, an extension and reflection of the legitimacy of the firm owner(s) so, future potential is conjured from the story as told but additionally, from the subject voice doing the 'telling'. Within the extant literature upon entrepreneurship, the detriment of femininity is well rehearsed (MacNabb et al., 1993; Ahl, 2006; Calás et al., 2009; Duberley and Carrigan, 2012) yet, how this translates specifically into entrepreneurial legitimacy is less considered. Axiomatically, from the arguments developed here, we would suggest that given the masculinity which imbues the entrepreneurial discourse and related identity work necessary to be recognised as an entrepreneurial actor, the legitimation process is critically gendered. Drawing these arguments together, we explore the degree and type of identity work women undertake when seeking legitimacy as credible characters with a viable voice in the entrepreneurial narrative.

\section{Technology and entrepreneurship}

It has been argued that technological advancement and innovation has potential as a nongendered site given its objectification and separation from the biological body (Woodfield, 2000; Shire, 2009). Critics of such claims however, argue that within this field there is a gendered order whereby women are positioned as designated end users of technologies whereas men have primacy as innovators and designers (Landström, 2007). Thus, the ethos of technology is embedded within masculinity and so, generates a related fraternity that effectively marginalises the feminine (Wajcman, 2004; Walby, et al., 2009). As Lohan and Faulkner (2004: 319) argue, 'technology is an extremely significant site of gender negotiations in relation to occupations, symbols and identities. Science and technology are widely acknowledged as power motifs of hegemonic masculinity'.

Unsurprisingly therefore, women constitute only between five to fifteen percent of technology entrepreneurs within Europe and register a fraction of patents for innovative products and processes (Walby et al., 2009; Wynarczyk and Marlow, 2012). Consequently, despite increasing numbers of appropriately qualified women, relatively few achieve seniority within formal careers and even fewer become entrepreneurs. Despite this, some women clearly do found new technology firms and so we now turn to explore, analyse and describe how and under what circumstances four women realised such ambitions. In particular, we now explore how these women reflexively craft their subject identities to gain legitimacy within the masculinised environment of incubated high technology entrepreneurship.

\section{Business Incubation}

Business incubators are bespoke office/laboratory spaces where an array of tailored support services are provided for young entrepreneurial firms (Hackett and Dilts, 2004; Hytti and Maki, 2007; Patton, 2013). At a practical level, the incubator is a site where business founders 
and those external to, but embedded within the entrepreneurial endeavour, interact. Accordingly, this is where entrepreneurs, business advisors and external professionals can meet and engage; thus, new firm owners and those acknowledged as experts in shaping and enhancing entrepreneurial legitimacy are positioned in proximity. Considerable debate has ensued regarding the role and influence of incubation in supporting and promoting young entrepreneurial firms particularly whether bespoke advice and support can be effectively leveraged to overcome the liabilities of newness (see Patton, 2013 for an overview). Whilst the extant literature regarding incubation recognises its diversity [so, public/privately funded; specific sectoral expertise; university/science parks] the focus remains largely upon the neutral substantive advantages and disadvantages arising from the business process (Rice, 2002; Scillitoe and Chakrabarti, 2010).

What is lacking in this debate however is a conceptually embedded critical analysis of the assumptions informing the role, rationale and objectives of incubation. The dominant assumption within the extant literature is of a social and physical space where the tenants, incubator managers and professional advisors interact in a neutral fashion. As such, prevailing theoretical presumptions focus upon the entrepreneurial firm as an objective unit of analysis with the support initiatives and physical benefits of incubation presented as impartial independent elements. It is this narrow and limited assumption which we question by theoretically repositioning the technology incubator as a social arena which is specifically gendered as masculine and as such, requires female tenants to undertake particular forms of identity work if they are to be recognised as legitimate within this environment. This creates a context where reflexive identity work is guided towards particularised entrepreneurial performances deemed to be normative and credible. Within this article, we question this axiomatic assumption of legitimacy and challenge the basis for these normative assumptions through a critical evaluation of the experiences of four female technology incubator tenants. This framework draws upon a number or fundamental constructs which inform contemporary analyses of entrepreneurship but which are rarely analytically combined to effectively progress theoretical development. Hence, we combine these notions within our research question which, as noted explores the reflexive identity work undertaken by women to gain legitimacy as credible entrepreneurs within the masculinised environment of high technology business incubators. To action these constructs, we now describe our methodological strategy and related method which act as scaffolding for our empirical findings.

\section{Methodology and method}

In framing this article, we have argued that as reflexive individuals, people draw upon available discourses to make sense of and enact with reality (Watson, 2011). When referring to 'discourses', we draw upon the work of Kelan (2009: 68) who argues that these are not comprised of just linguistic narratives but include, 'spoken, written and acted texts' and 'the way one dresses'. In addition, we recognise that discourses are also positioned in physical spaces which influence whether the individual is recognised as a credible occupant or interloper (Tyler and Cohen, 2010). As such, discourses are diverse frames of reference which inform, constrain and/or enable our enactments of culturally and contextually appropriate behaviours. Accordingly, we consider entrepreneurship to be a process and performance which has cognitive and physical components which those who create new ventures will encounter, negotiate and reproduce. We acknowledge the importance of issues such as those of social construction, researcher interpretation, and narrative/discursive framing without 
denying that there are realities which exist in the social world (Watson, 2011). Thus, we explore, interpret and analyse the experiences of women coping with the reality of founding and managing new technology ventures in the context of business incubation.

Detailed empirical material was generated from an exploration of the experiences of four women who had left senior ICT corporate management positions to begin and grow new high technology firms within business incubators. The case studies were constructed over several periods of semi-structured interviewing, non-participant observation and follow-up discussions to clarify and expand upon key themes emerging from the analysis phase. For the purposes of exploring how the respondents had arrived in their current roles as hightechnology entrepreneurs, we asked them initially to reflect upon the background to this decision and what had fuelled their current entrepreneurial ambitions. Having established case backgrounds, we then focused specifically upon their recent experiences of business incubation to gain a sense of how this had influenced and shaped the enactment of an entrepreneurial identity and related effects upon legitimacy and credibility.

\section{Research contributor profiles.}

The four women, whose entrepreneurial identity work forms are the subject of this study are described in Table 1. Each was afforded a pseudonym to preserve anonymity; the research was undertaken between 2009 and 2011.

\section{Insert Table 1 here}

Each woman had left senior ICT corporate management positions and had commercialised an innovative idea through new venture creation and all had formal qualifications, technical expertise and managerial experience. Ostensibly, this profile represented a good fit with the ideal incubator tenant except for one particular liability which disrupted role suitability, that of gendered ascription. So, whilst convincing in respect of entrepreneurial potential, this possibility was contained within the 'wrong bodies' (Butler, 2004). Addressing this gendered dilemma requires particularised identity work ranging across a number of scripts and texts in the effort to claim legitimacy and recognition as a technology entrepreneur. It is recognised that the present study is limited by its focus upon a very particular sector of the entrepreneurship economy. It was, however, a deliberate choice to explore the experiences of women entrants to what is an acknowledged fraternal culture (Servon and Visser, 2011). We note that this approach reflects similar feminist analyses of women's experiences of career progression and discrimination in male dominated occupations (Kelan, 2009). Focusing upon particular niches enables us to avoid the problems of generic assumptions but also, enables the extraction of analytical themes which can be applied to and pursued within other sectors of the research field where women are marginalised actors.

At this point, it would be expected that some discussion of the ideal number of cases necessary to offer detailed illustration of the key elements of the analytical framing might be offered. However, this is somewhat redundant as within the locality, a small advanced social welfare oriented economy (total population, 4.4 million), during the period of the study (2009 - 2011) searches of public sector, private and university business incubators revealed four tenancies where women were the lead/founding entrepreneur (this resonates with the very limited existing literature where such women are equally rare in larger economies (see 
Marlow and McAdam, 2012). However, although a relatively small economy, similar to larger counterparts, there is a presumption that women have a right and obligation to be economically active. In recognition of gender based barriers to female economic participation, there is a raft of equal opportunities/family friendly regulation in place within employment to encourage women to combine domestic and waged labour ${ }^{1}$. In addition, there is considerable enthusiasm for entrepreneurial endeavours with specific government policies aimed at women to assist them in overcoming the alleged entrepreneurial deficit of femininity (Ahl, 2006). Thus, there is a strong egalitarian culture which, it would be assumed, promotes greater parity yet, in accordance with other western economies, there is gap between the rhetoric and reality of the post-feminist equality agenda (McRobbie, 2009). Therefore, despite the centrality of the entrepreneurial project and dedicated support for women entrepreneurs, they form a very small minority of those who start and grow technology oriented ventures (Wynarcyzk and Marlow, 2012).

Fortunately however, all four women agreed to contribute to the study and discuss their experiences of incubation, entrepreneurship and business growth strategies and practices. Although a small sample, this falls within the accepted range constituting multiple case analyses facilitating the identification of themes to inform theorising (Sigglekow, 2007). In addition, the wealth of contextualised material generated accords with the rationale of interpretive research regarding theory development where thick description and contextualised scripts are conceptually embedded in analytical frames. Convincing links to theory arising from in-depth analyses addresses 'spatial limitations' (Clegg, 2009: 157). Furthermore, triangulation was achieved as these four cases were supplemented by observations, attendance at investment seminars, conversations and follow-up discussion; thus, generating a fine grained detailed picture of the past, the present and envisioned futures.

The interviewing schedules framed guided conversations - the stories which emerged however, were freely narrated responses, the questions acting to direct recollections and explorations around the key themes of gender, identity work and entrepreneurial legitimation. Following Boje (1991), the researcher acted as an informed listener attempting to 'get the story straight' but at the same time, encouraging the discussion towards the analytical underpinnings of the study. As Golombisky (2006) argues, there is a bias within the contemporary social science research agenda which rarely reflects upon whose voice is given priority as the definitive arbiter of the dominant discourse. Whilst this has been challenged through feminist critique in fields such as critical management studies (see for example, Ashcraft, 2011); this is rarely acknowledged in the entrepreneurial field. Indeed, a comprehensive review of the influence of gender upon entrepreneurship (Neergaard, et al., 2011) found very few critiques which drew upon a feminist stance or offered a meaningful voice to the female subject. Thus, Hughes et al., (2012) argue for challenges to established epistemological perspectives which produce and reproduce the biases noted by Golombisky (2006), by emphasising the female voice we are able to critique notions of legitimacy and incubation as impartial constructs. As such, we articulate a feminist stance and so, foreground women normatively subsumed within the allegedly gender neutral agenda of business

\footnotetext{
${ }^{1}$ As is evident however, such policies and practices ostensibly make space for women's economic participation whilst not challenging the prevailing institutional assumptions which actually constrain their agency (Martin, 1991; Carrigan and Duberley, 2012).
} 
incubation. In so doing and by listening to their portrayals of everyday life within the incubator, we question and challenge the assumed impartiality of this environment.

Whilst the point of detailed, qualitative enquiry is to elicit depth and detail, this presents challenges in drawing out salient issues and ordering the material generated. To address this issue, we began the analysis by reading through transcripts and identifying and comparing initial concepts and grouping them into provisional categories (Strauss and Corbin, 1998). The data analysis process which we followed is detailed in Table 2.

\section{Insert Table 2 here}

We then sought to identify ways in which these categories related to each other and the key themes within our framing analysis (Locke, 1996; Strauss and Corbin, 1998). This process is not linear but rather develops through a dialogue between the researchers and the respondents. A 'recursive, process-oriented, analytic procedure' emerges (Locke, 1996: 240), drawing out key theoretical relationships. This process resulted in the following stories which reflect the key themes within the literature and are made up of the strands which emerged from the data. Table 3 summarises the final data structure.

\section{Insert Table 3 here}

To present a coherent analysis of the findings, each theme is explored in detail illustrated with fragments of the narrative; more comprehensive excerpts are outlined in Appendix One which indicates how the interview dialogue informed the discrete themes (Pratt, 2009). Inevitably however, to distinguish between reportage and analysis, the researcher acts as collator and interpreter of shared stories and so, takes an authoritative role. Thus, it is recognised that such analyses are inevitably filtered by the researcher's perspective and in addition, biased by prevailing epistemological assumptions (Golombisky, 2006; Ahl and Marlow, 2012); accordingly, to ensure descriptive validity (Maxwell, 2002), the thematic threads were shared and discussed with each contributor. This enabled refinement of these strands, additional insights and comments were also invoked but importantly, the women confirmed that the narratives captured and reproduced their voices which accordingly, have not been lost in our translation.

\section{Stories of Technology Entrepreneuring}

\section{Identity and Identity Work}

\section{Gendered Performances as managers and technology entrepreneurs}

It is widely acknowledged that the majority of new firm owners move from waged employment to self-employment (Storey and Greene, 2010; Greenman, 2012). Prior employment is a critical contributor to entrepreneurial resources such as market knowledge, managerial competencies, network membership et cetera and so it was the case here. Each woman had developed an innovative product or process enhancement related to their previous industry experience. Consequently, the first coherent theme which emerged arose from discussions regarding how managerial careers had acted as a back drop to entrepreneurial careers, 'to me, going on my own was only possible because of what I learnt 
in my job; that was my jumping off point. This is sort of the next logical step for me' (Prue). Kim also emphasised the value of her previous career experience in providing her with transferable skills and competencies but in addition, she acknowledged that there was no organisational safety net to fall back on if things went wrong, the particularised risks of entrepreneurship, both personal and professional, were keenly recognised, 'my previous career gave me invaluable experience; I mean I learned the ropes but this is different - it sinks or swims with me - if it all goes wrong, it would be me that failed as well' (Kath).

It was also apparent that seniority in previous careers contributed to confidence building prior to start up; 'I managed to build up useful networks over the years, I got lots of feedback and tips from colleagues when I was thinking about the business; I also had insider knowledge on potential customers so I was ready' (Kim). Yet, in terms of managerial/career legitimacy, the respondents offered many examples of their marginal group ascription; they each had appropriate qualifications and managerial experience but these were tempered by gendered overtones. We offer just a few narrative examples; 'I remember when I got my first 'senior' job, one bloke said, 'Thank God you're here, we need a girl at the meetings to chat up the clients and keep the difficult ones sweet and all the others nodded - it was their way of making me welcome I guess' (Prue). When applying for promotion, Kath was asked to take a typing test even though the post had secretarial support but, 'it was just part of the procedure for all women who applied for internal promotion as the assumption was that you would be a secretary, PA or admin person'. Analyses of organizational subcultures illustrate the tensions between gender and managerial legitimacy (Lewis and Simpson, 2010) which is exacerbated within technology work (Kelan, 2009). As such, there is a dual effect from the masculinity embedded within both these contexts which promotes self-reinforcing homophily. This, in turn, requires women to adopt particularised strategies to enact credible identities to address the tensions arising from being situated within the 'wrong bodies' (Butler, 2004).

Kath focused upon achievement and in her case, over-achievement; "I was aware that as a woman, it was assumed you'd be lightweight so I often worked 17 hour days - a lot harder than most of the blokes'. During the narrative conversations regarding these attempts to be 'one of the boys' as Prue put it - none of the women interpreted their experiences as responses to embedded subordination. Even though each woman recounted instances of sexist discrimination it was assumed that contemporary equality policies had eliminated such behaviours creating what Kelan (2010) refers to as a 'gendered dilemma'. This dilemma arises from the dissonance of simultaneous denial and experience and was addressed through interpreting discriminatory behaviours as individual idiosyncrasy or organizational norms, 'they (male colleagues) can't help themselves sometimes, it's just how it works in this industry, you just need to manage it' (Kim).

Despite such efforts to interpret the prevailing gendered regime bounding their managerial careers as anodyne and navigable, when encouraged to reflect upon the extent (if any) these experiences impacted upon the switch to an entrepreneurial career, these influences were acknowledged; 'the IT sector is really chauvinistic, so I thought that at least if I was my own boss, it would be one less thing to deal with' (Kim) whereas for Sharon, 'on reflection it can be tricky being a female in ICT but that's just how it is, I don't think it's personal but it can be very wearing'. Despite perceptions of gendered regimes as culturally normative, it was agreed that one of the attractions of entrepreneurship was being assessed through the proxy of the 
firm. As Kath remarked 'Being your own boss means no one is likely to ask you to take a typing test; I mean it's your business and it's a success or it isn't'. As has been argued, on-going identity work is undertaken by all social actors to present a readable subject but, such work is a contextualised enactment. In these cases, the women told a story of moving from a context of managed gender bias to one which they believed should offer greater autonomy. In effect, the new venture is considered a representation of the self; the person and the firm become an amalgam such that the objectivity of the former might overcome the subjectivity of the latter. So, entrepreneurship was pursued with the aim of commercializing a marketable idea but, when converting the nascent idea into an actual firm, a legitimate entrepreneurial identity must be articulated which can be recognised by key stakeholders and so, enabling the venture to be enacted (Wry et al., 2011). It is the role and influence of the incubation process in legitimating the venture which informs the next theme.

\section{Business Incubation}

\section{Legitimating the business; legitimating the individual}

Having described how managerial careers informed and shaped the decision to begin a new venture whilst also providing critical entrepreneurial capital to do so, the woman then described how the firm initially took shape. Each woman consulted a professional business advisor who directed them towards business incubation. All had successfully presented their business proposal to the incubator board but even at this stage, the gender imbalance of the process was noted; Prue summarised this with her comment, 'In all my interviews to get in here, it was just me and room full of white men in suits'. So, whilst the competitive entry process into the incubator had been negotiated ostensibly on the quality of the business idea, from the onset, the women were marked as different; 'I think my business is fantastic and it's proved itself but I know I ticked a lot of boxes here, I knew my stuff and I was female; that comes up a lot - believe me' (Sharon): 'actually, they took very kindly to me which I suspect was something to do me being a girl' (Kim). Although Kim stated that she demonstrated the required entrepreneurial potential to be deemed credible as an incubator tenant, being female was influential and, on this occasion, advantageous - she was treated 'kindly'. We see the paradox of gendering here; Kim believed this 'kindness' arose as an acknowledgement of her being feminine (so women must be treated more gently/kindly/sensitively than men) but this benefited her tenancy application which, this implies, was not considered by merit alone.

As is widely recognised (Mac an ghaill and Haywood, 2007; McRobbie, 2009), gaining advantage from assumptions of gendered weakness or difference is a limiting strategy; quite clearly, individualised gains can be attained but norms of visibility and disadvantage are further embedded. Indeed, Kath remarked, 'they like having women here - we are a novelty so, it's a plus for them but l'd hoped to get away from that'. Gendered ascriptions are not something one can 'get away from', but are sensitive to context (Bradley, 2007). An informative example of gendered positioning occurred during external seminars; as was observed by the research team during such events ${ }^{2}$, conversations with the women were often qualified by specific references to their gendered subject position: 'you must meet one of our lady entrepreneurs' whilst one conversation required an incubator manager to specifically identify Kim as a business owner to an external finance advisor, 'Oh yes, she has a

\footnotetext{
${ }^{2}$ which had on average had a 5:1 male to female ratio with regards to attendance
} 
tenancy here; it's great having some girls to brighten up the place - they have some good ideas too'. One particular business mentor used the following sentence to introduce Kim to a group of external advisors, 'ah yes, I must introduce you to Kim, she's very special to us', going on to extol her business achievements. Whilst this notion of 'special' could be taken as a compliment to her entrepreneurial success and competency, the comment was subtly qualified through a final element of the conversation which ended with 'and she has a husband and children at home too'. From the analysis of notes taken at such events, none of the male entrepreneurs were presented as 'a gentleman entrepreneur'; rather, they were introduced as a personification of the business idea, 'you will be interested in this proposition - a resource management system' and to our knowledge, during introductory exchanges, none were afforded additional identities of husband, partner or father.

These gendered scripts illustrate how, when the women encroached into male dominated spaces, they became defined in terms of an extraordinary presence whereas men, as natural inhabitants, fulfil normative identity codes (Wry et al., 2011). Thus, as we have argued, transgressing gender norms requires specific forms of identity work to claim (male) competence without threatening heteronormative ordering. Yet, as identity construction is an iterative relationship, women may claim legitimacy through specific qualifications and competencies but if these contradict prevailing norms, they may not be recognised. Prue ruefully noted, 'they (peers/advisors/investors) really struggled with me as a systems designer but had no problem chatting about kids and schools'. Such interchanges re-position women in congruent roles such as 'mother' and in effect, re-establish the gendered order despite contrary claims to roles such as a systems designer.

A particular area of tension emerged from analysis of the narrative scripts; whilst identifying various forms of benign patriarchy (being considered special, treated kindly) the women were prepared to engage with what Sharon referred to as 'game playing'. In effect, this meant utilising male credibility to compensate for a lack of female legitimacy particularly when engaging with external professionals who struggled to reconcile femininity and technical competence. As Godwin et al., (2006) suggest, a critical strategy for women to establish entrepreneurial legitimacy is to partner with men; as such, to benefit from osmotic credibility. This is illustrated by Kim's comment on managing her investment meetings, 'I knew that strategically I had to take a bloke in there; the finance guys would have dismissed me; it's not a problem now as the business speaks for itself'. This comment is particularly telling; as a women Kim did not merit confidence but, it is notable how the business has become reified as the source of her credibility rather than her talent and skill in developing it. Whilst now challenging the requirement to establish her credentials through male condonement, she suggests that it is the business not she, who now commands respect. Accordingly, substantive achievement has been filtered through a neutral construct (business performance); in effect, entrepreneurial legitimacy has to be negotiated and claimed through specific performances which then compensate for the liability of femininity. This fragment of the narrative also relates back to our notion of the female voice which, it is argued, is overshadowed by that of men (Kristeva and Menke, 1989). In this case, the business is the voice of legitimacy rather than Kim as the creator and leader of this venture; she suggests that as a women her physical femininity and related lack of authority in terms of voice and presence requires reinforcement initially, by the presence of a male champion and second, by the substantive performance record of the business. 
An additional insight into legitimating strategies was evident from the use of business mentors. Finding an appropriate mentor emerged as pivotal as they provided a legitimacy script' in being informed directors of appropriate behaviours in addition to being repositories of professional advice and network brokers. All of the business mentors were men and indeed, the woman expressed a preference for a male mentor - 'I wouldn't want a female mentor because I'm so used to working with blokes and anyway, you know they have been there and done it, it rubs off on you' (Prue). The legitimacy premium afforded through sponsorship from credible group members for those on the margins is well rehearsed (Godwin et al., 2006) In perhaps one of the most powerful, or indeed, poignant comments from the collective narratives, Kim stated that the greatest value of her mentor was that he guided her in, 'learning how to think properly, learning to think like a man'. Kath however, also discussed how one mentor contravened her expectations as she felt he focused too much upon her femininity;

'it's because I'm female but he (X) always asks how I'm feeling, and he's always interested in how I'm feeling but I think we're talking too much about my feelings so what I have started to do is leverage off (alternative mentor) so I just go directly to him and then, once a week (meeting with X) I talk about my feelings; it keeps him happy'.

From the analysis of these narrative themes which reflected upon the experience of incubation, what emerges is a process of reflective accommodation. The women recognise how gender shapes and differentiates their presence - being treated kindly and expected to discuss their emotions but equally, they subscribe to this by 'playing the game'. As such, these women engaged with iterative identity work through engagement with the dominant referent groups (Ibarra, 1999] within the incubator to inform their search for technological and entrepreneurial legitimacy. Managing this process required considerable effort to enact a diverse range of required scripts; drawing from the narrative accounts, many of these aspects were captured within approaches to dress and space which we explore as our final theme.

\section{Dressing to fit the space}

When defining notions of discourse, we acknowledged the symbolic diversity of this construct noting that physical aspects such as forms of dress and the use and occupation of space are integral elements of such - alongside text and language. In discussing their managerial careers, dress codes were a frequent topic of conversation, 'I was also careful to look very professional in what I wore; smart suits and usually, trousers to blend in' (Kim). Whilst Kath remarked 'it's important to dress smart and look the part as a business owner; you can't turn up in your floaty dress; you'd be a laughing stock and rightly so I mean, you have to be the badge of the business so that's how you need to look'. In an insightful comment Sharon noted, 'It was tricky, finding that happy medium between smart tart and plain Jane-being professional but not losing sight of being female, it was a pain actually'. We were interested to explore if being the firm owner with the autonomy this implies, effected attitudes to dress and presence. It became apparent that presenting a credible personification of the new firm had gendered dimensions. So, as technology venturers, the women [just like their male counterparts] had to present themselves as convincing and competent. Yet, as women [unlike their male counterparts], their gender formed the backdrop to a devalued socially 
constructed articulation of identity and legitimacy. Consequently, this analysis of dress and presentation reveals that the respondents are not just technology entrepreneurs who happen to be women, but women who happen to be technology entrepreneurs. All the respondents made some comment that their dress code was focused upon presenting a credible professional presence but one which did not fully refute femininity, 'it's the fine line between being professional but not dowdy; being a girl can be an advantage so don't downplay that' (Prue).

The narratives around this topic [see Appendix One for further detail] were telling in illustrating how carefully the women policed their appearance to present what they considered legitimate personifications of their businesses (to claim entrepreneurial legitimacy) but also of their femininity (to maintain social credibility). Complying with normative dress codes pervades all aspect of social interaction thus, using dress to generate a credible situated image is not applicable only to women. However, what did emerge was the nuanced nature of this performance which did render it gendered as all of the women alluded to the necessity of presenting the self as a legitimate representation of the technology entrepreneur and a woman. Finding the balance between a neutral presentation of the self and recognition of the gender imperative required consideration; this rather lengthy quote from Sharon summed up the discussions around this area:

'I still wear my suit uniform even though I am now in charge but you have to give the impression of professionalism particularly to those who don't understand the technology and of course, being a woman they don't believe you understand it either. But you don't want to be too mannish I mean, it's hard enough doing this; if you can get the boys on side with a few feminine wiles, why wouldn't you so no point in dressing in a sack. Heels and a bit of lippy help too'.

Accordingly, self-management through consideration of how the body was presented in terms of dress which spans femininity and contextual competence was a constant and selfreflective project sensitive to the intersection of entrepreneurship, technology and incubation.

\section{Discussion}

From the analysis of the findings, three critical themes emerged with related sub-themes: first, identity and identity work (enacted as a gendered performance in the context of technology entrepreneurship), second business incubation (as a legitimising device) and finally, dress and space (coded interpretations of fit]. To illustrate these themes, we described fragments of the extensive narrative accounts shared by the respondents.

\section{Identity and identity work as a gendered performance}

Reflecting upon their previous careers, the women struggled with the contradiction of gender denial whilst negotiating embedded bias. Accordingly, whilst enacting specific identity work to blend in with the masculinised status quo and so claim group credibility, they recounted numerous stories of how they were positioned and re-positioned through their gendered subjectivity whether in using their femininity to deal with a difficult client or having to take a typing test. Such expectations were deemed a normative element of the ICT culture where there are relatively few women and indeed, even fewer as senior managers (Duberley and 
Cohen, 2010). Consequently, the combination of a fraternal culture and minority status positioned these women on the margins of the dominant group - required to enact specific identity work to claim affiliation with and recognition by existing incumbents (Ibarra and Barbulescu, 2010; Kenny, 2010). Accordingly, whilst the women were prompted to begin new technical ventures through the development of innovative ideas with commercial viability, they believed that entrepreneuring would be a site of greater gender neutrality with the critical focus upon the firm rather than the founder.

However, the findings suggest that these women were encouraged to replicate dominant masculinity and so blend with the gendered status quo within the incubator. Simultaneously, they recognised the impossibility and indeed, the undesirability of trying to renounce gendered ascriptions given the danger of losing viability as human subjects. So, although obliged to draw upon situated cues to undertake nuanced, reflexive identity work to reproduce the legitimated imaginary technology entrepreneur, the social expectations and conventions which embed the gender binary as symbolically fundamental to human interaction ensured that these divisions remained intact. Basically, women can emulate aspects of masculinity but must do so without overtly offering a 'gender threat' (Fine, 2010); to do so is to invite social ostracisation. As such, the incubator acted as an induction or socialisation (Ibarra and Barbulescu, 2010) device as those who influenced entrepreneur behaviour through their expert advice and support reproduced a gendered script. This again exposes analytical inconsistency given the suggestion of an agentic actor [through the act of being entrepreneurial) who, to be deemed legitimate, has to recognise and reproduce particular identity work. Through the analysis of this contradiction, entrepreneurship is revealed as an invidious process suggesting potential for emancipation through agency whilst in fact, bounded by institutional constraints.

\section{Business Incubation as a legitimating device}

Using the technology business incubator as a contextual backdrop to analyse the process of gendered identity work in the search of entrepreneurial legitimation enables us draw these constructs together to contribution to these contemporary debates. Although substantively qualified to claim recognition as technology entrepreneurs given their qualifications, experience and business concept, the overlap between the masculinised discourses of ICT and entrepreneurship positioned these women at the boundary edge of the incubator community. Of course, for those seeking legitimation as valid technology entrepreneurs, incubation tenancies offer substantive advantages, including advice and direction in how to tell a convincing story of the envisioned future of the firm to resource stakeholders. For these women however, it was apparent that this story had to foreground the masculine voice to be recognised as legitimate and so, for the female tenants, this particular facet of incubation was acknowledged as critical - 'learning to think like a man'. Thus, incubation worked as a process of induction, enabling the women to draw upon critical social cues to inform their identity work and so, reproduce and enact the idealised technology entrepreneur. Consequently, contextualising this study within the business incubator raises critical insights regarding the potential gender bias embedded within this form of business support. Whilst there is a welldeveloped literature exploring the processes and benefits of incubation, there is very little 
acknowledgement of the gendered presumptions and environment shaping this important source of business support ${ }^{3}$ for growth oriented firms.

Developing our analysis through a gendered perspective also illustrates the bias integral to incubation - a critical form of business support which facilitates supports and enables the transformation of business concepts into commercial ventures. In effect, the women in this sample had achieved a much sought after incubator tenancy suggesting professional interrogation and support for their business idea. Such acceptance in combination with their technological/managerial career credentials suggested they were well positioned to relate a convincing tale of entrepreneurial legitimacy. And indeed, the incubation process must be considered successful as each woman had commercialised their ideas; all had attracted investors, grown their firms which appeared to have future viability. Yet, evaluating the incubation in the context of the interface between gender, technology and entrepreneuring suggests that the potential for demonstrating credibility was constrained by a specific script which positioned women within a gendered space in the prevailing discourse. To compensate for this, the women not only enacted but also, were tutored in specific identity work to address the deficit of femininity in terms of technological experts and entrepreneurs. The enigma of this being that those who were complicit in re-shaping the women's behaviours to align with legitimate norms, such as mentors and the incubator managers, simultaneously related to the women as different. What emerges from this analysis of the incubation context was a cognitive space where the incumbent members - entrepreneurs, business managers, professional advisors - subscribed to a consensual vision of the enactment of a legitimate technology entrepreneur fuelled by the popularised image (Radu and Redien-Collot, 2008) of the entrepreneurial identity per se. As such, these findings reveal that the transition from senior ICT manager within a large corporate to entrepreneurial firm owner for these women entailed a shift from a gendered regime gilded by a thin veneer of equality rhetoric to one gilded by a slim rhetoric of autonomy and self-realisation.

It is acknowledged that the legitimation process of new ventures, the stories relayed in this study resonated with the extant evidence (Tornikoski and Newbert, 2007; Wry et al., 2011) which describes the complex process of claiming entrepreneurial legitimacy in the absence of institutionalised norms informing the sense making process. It is acknowledged that the construct of entrepreneurial legitimacy has been explored at length (Lounsbury and Glynn, 2001; De Clercq and Voronov, 2009; Wry et al., 2011). An emphasis upon novelty and differentiation and an absence of a track record whilst seeking to demonstrate field congruency renders the entrepreneurship legitimation process inexact and largely intuitive. Entrepreneurs need to present compelling stories drawing upon familiar anchoring events from the past to create a convincing vision of the future with the ambition of diminishing the risks associated with the potential venture (Cornelissen et al., 2012). Within this scenario building process, the subject identity of the entrepreneur embodies the articulation of a projected future thus, the individual's entrepreneurial credibility is a crucial component of claims to, and awards of, legitimacy. Yet, our analysis and findings suggest seeking and gaining legitimation is a contextualised gendered activity which must be revealed as such to inform current theorising and to question representations of this as a neutral process.

\footnotetext{
${ }^{3}$ It is noted there are 'women only' incubators but whilst offering bespoke support, it is uncertain that separating women in this way assists entrepreneurial legitimacy. Rather, this potentially positions women as other and so emphasises special needs which, we suggest undermines normative legitimacy claims.
} 


\section{Dressing to fit the Space}

As Levi (2006) notes, stereotypical notions of gender and gendered behaviour are enacted through expectations of how men and women should look and dress. Indeed, Butler (1993: 2004) has explored the notion of gender as a performative through analyses of cross dressing and the dissonance this creates through the generation of gender 'threat' arising from destabilising the normative gendered order made visible through dress codes. Conformity to broader notions of gendered dress is a critical aspect of human identity work; it makes us making us recognisable subjects - such forms of dress have to be appropriate to reflect specific social settings and the organisational environment. However, as social subjects we are obliged to recognise and reproduce normative forms of dress which act as legitimising signals to ensure 'fit' with the preferred referent group; transgressing too far into the dress territory of the opposite gender is dangerous as it raises the notion of threat to established norms (Butler, 2004). Thus, finding the correct balance to fit whilst not representing threat is a balancing act in which organisational cues are essential to showcase acceptable and conversely, unacceptable choices.

However, as has been suggested from these findings, using dress codes to blend in is not simply a question of conforming with dominant norms as ascribed social characteristics intervene with the dress options available to the individual. So for example, Bjorkman et al. (1997) note how specific forms of dress are used by women to adjust to male dominated cultures; adopting external trappings which reflect masculine norms assists in concealing overt femininity enabling women to blend with the prevailing context. Finding this balance is exacerbated where individuals transgress into situations where they are marginalised or characterised as different. This has been explored within the field of management and particularly, how senior female managers police their appearance to seek authority and status as managers without transgressing femininity (Levi, 2006). The women contributing to this study explored the dress issue at length and the subtly of achieving the correct balance but in addition, their comments illustrated how this had been carried over into entrepreneurial careers. However, it was notable that the importance of dress related to a legitimacy transfer process; rather than confirming individual professionalism and status to a managerial career, appropriate dress was necessary to transpose the legitimacy of the person onto the entrepreneurial firm. Where the individual was a poor fit - as is the case here in terms of gender incongruence as a technology entrepreneur and incubator tenant - trappings such as appropriate dress were crucial as a device to blend into an unsympathetic space.

Consequently, drawing these issues together suggests that creating new firms in the context of incubation enabled each woman to leave previous unsatisfactory employment and realise their own entrepreneurial ambitions. Yet, adopting a contrary feminist perspective suggests four women who swapped one gendered culture of constraint [employment] for another [self-employment] - but one in which the nature of bias is disguised under the cloak of agentic achievement and personal effort. Within this process, incubation is positioned as a benign and neutral form of support and advice; the evidence described challenges this assumption.

\section{Conclusion}

Hughes et al. (2012) argue that analyses of the influence of gender upon entrepreneurship now need to extend into new directions to contribute to theoretical advancement and 
sophistication. Within this article, we aim to contribute to this endeavour through the exploration of our critical research question focused upon the influence of gender upon the reflexive identity work undertaken by women technology entrepreneurs in the context of business incubation. In concluding our arguments we identify a number of contributions to debate and theory development, outline suggestions for future research and note the limitations of our arguments.

The gendered interplay observed within the allegedly neutral environment of incubation illustrates how institutionally embedded notions of gender shape and influence entrepreneurial identity work, options and processes. Thus, we concur that the legitimation process is one of fitting in whilst standing out (De Clercq and Voronov, 2009) but we advance this literature by illustrating the interjectory influence of gender within this process. But, responding to the pressure to fit in is not just a case of adjusting and realigning identity work; as is demonstrated in the context of technology incubation, for women, being singled out in this way is in tension with the desire for and pressure towards isomorphic legitimation. Consequently, our feminist perspective generates an alternative theoretical approach; we challenge the alleged 'common sense' assumptions regarding gender impartiality and neutrality which currently inform and reproduce the narrow ontological scope of the legitimacy and incubation literatures.

Exposing and exploring this bias is essential to question incubation as a neutral form of business support and reveal the detrimental influence such bias may have upon the ambitions and actions of women business owners. What we have seen is the co-construction and reinforcement of stereotypical assumptions of gendered behaviours merely transposed to the incubation context. This raises the notion of a paradox; the purpose of incubation is ostensibly to encourage and empower entrepreneurial ambition. When analysed through a gendered perspective however, this process is annotated and filtered which in effect, limits legitimacy to those who can recognise and are able to reproduce specific scripts. Future research exploring incubation must acknowledge these physical spaces as socially biased contexts which reproduce institutionalised prejudices regarding assessments of eligible and legitimate incumbents.

Our exploration of the fusion between the entrepreneur and their potential venture utilising a gendered perspective contributes an additional dimension to the theorisation of entrepreneurial legitimacy. Positioning this analysis within the volatile field of technology venturing, where convincing stories of future potential are essential to accrue the range of entrepreneurial resources necessary to commercialize innovative ideas, generates greater transparency around this process. Critically, we argue that it is essential to recognise and evaluate the influence of ascribed characteristics within and upon the legitimation process; accordingly, the potential entrepreneur is positioned as a social actor operating within prescribed norms. As such, the stories told and the credentials presented will be interpreted through a particular and specific ontological framing which critically facilitates, or denies, legitimation. So, the contemporary focus upon the dialogue between legitimating stakeholders, entrepreneurial claimants and their ventures is limited. Future conceptualisations of entrepreneurial legitimacy must recognise how ascribed characterisations, such as gender, differentially position the credibility potential of the individual as the substantive representation of the future firm. The interface between the 
persona of the nascent entrepreneur and that of the firm is critical; this requires greater theoretical and empirical acknowledgment.

In terms of limitations, within this paper we have focused upon two business incubators operating within a specific sector. As such, we only offer theoretical generalisations from our analysis however, these can be deepened through explorations of gendered entrepreneurial legitimation within alternative forms of incubation - analysing how this works in women-only incubators for example. In addition, exploring the limited examples where women work as incubator managers or professional advisors may offer a different perspective upon the incubation 'induction' process. Although we focused upon women business owners, we acknowledge these are white, middle class women whose entrepreneurial resources are enhanced by their socio-economic profile. We recognise the need for intersectional analyses in a context of positionality (Hancock, 2007; Anthias, 2008) which considers gender ascription to be just one characteristic which places humans within particular spaces within the social sphere. Thus, in many respects, this article raises many possibilities to explore how the stories told to achieve legitimation are as much about the voice and body of the story-teller as they are about the story told. This must be recognised within the entrepreneurial field to progress our understanding of how concepts such as identity work and legitimation processes mesh to generate specifically gendered environments.

There are several implications which arise from this discussion for those working within the field of incubation as advisors and policy makers. Clearly, broader survey work is required to attain an accurate account of the number of women led ventures which achieve tenancies; this data would illustrate the gender disparity we suggest exists. By drawing attention to the imbalance will certainly not address the bias within the discourse but it will prompt debate and in addition, reflexive criticism upon the inequity of incubation. In terms of possible shifts in policy and practice, we suspect these would reflect the prevailing approach (Ahl and Marlow, 2012) which merely encourages women to adopt normatively credible performances to fit the existing script. However, by raising the issue, it would also facilitate alternative critical voices to challenge the norms of incubation and in so doing, perhaps encourage more women to apply for tenancies and also, prompt incubation management the associated policy makers to reflect upon the narrow agenda they currently sponsor. Consequently, the analytical critique we have developed in this article must inform future research which empirically demonstrates the prejudice and discrimination which currently, is a taken for granted aspect of incubation.

So, reflecting upon this discussion, we echo the suggestions by Bruni et al. (2005) that women business owners oscillate between the symbolic spaces of gender and entrepreneurship. Within the present study, we have described how this oscillation informs particular forms of identity work for women with ambitions to legitimate new technology ventures. As we argue, the legitimation process is not only one of credibility for the potential firm but also for the person who enacts the firm. On this basis, there appears to be a gendered script regarding how entrepreneurial legitimacy can be sought and awarded; how this positions both men and women in this debate requires further investigation and analysis to extend research in new directions. Consequently, this paper raises far reaching concerns over the scope of business incubation as a business support mechanism. Drawing upon these arguments, we would suggest that incubation is potentially a detrimental and damaging influence given the lack of 
reflexive critique upon the embedded masculinity within the process. There is a largely camouflaged gendered script within incubation which is not recognised in current research; in effect, the assumption that femininity is a 'doing' and masculinity a default is again revealed. Finally, we argue that the arguments raised here have far-reaching implications. The disguised impartiality of incubation and legitimacy is replicated throughout much 'mainstream' theorising (see Martin [2000] for a related comment upon organization theory research) and this trend is actually acerbated by the recent emergence of women's entrepreneurship as a cypher for gender research. Indeed, the notion of gender is now fully recognised but we would raise the suggestion that the manner in which this construct is mapped almost exclusively onto women, and is articulated as discussions of women, is in danger of creating a feminised enclave. Thus, the 'women box' is being ticked in such a way as to offer a free pass to the ontological foundation of current theorising; it remains as it ever was whilst the gender ticket is being franked through discrete analyses of the problem of women rather than theoretical articulation of gender. Within this article, we have attempted to expose this trend by critically evaluating how assumptions surrounding legitimacy and incubation are biased and partial which generates an imperative for women to enact gender in a manner which men are not obliged to do. The problem does not therefore, lie with women but the manner in which mainstream theorising is steeped within masculinity under a masquerade of neutrality; this must be challenged to advance theoretical debate and empirical enquiry. 


\section{References:}

Ahl, H.J. (2006). Why research on women entrepreneurs needs new directions. Entrepreneurship Theory and Practice, 30(5): 595-621.

Ahl, H.J. and Marlow, S. (2012). Exploring the dynamics of gender, feminism and entrepreneurship: advancing debate to escape a dead end? Organization, 19(5): 543-562.

Anthias, F. (2008). Thinking through the lens of translocational positionality: an intersectionality frame for understanding identity and belonging. Translocations: Migration and Social Change 4(1):5-20.

Ashcraft, K.L. (2011). Knowing work through the communication of difference: A revised agenda for difference studies. In D.K. Mumby (Ed) Reframing difference in organizational communication studies: Research, pedagogy, practice (pp.3-29). Thousand Oaks, CA: Sage.

Beck, C. (1992). The Risk Society. London: Sage.

Bjorkman, C., Christoff, I., Palm, F. and Vallin, A. (1997). Women in Computing. Exeter: Intellectual Books.

Boje, D. (1991). The storytelling organization; a study of storytelling performance in an office supply firm. Administrative Science Quarterly, 36(1): 106-126.

Bradley, H. (2007). Gender. London: Polity Press.

Bruni, A., Gherardi, S. and Poggio, B. (2004), Entrepreneur-Mentality, gender and the study of women entrepreneurs. Journal of Organizational Change, 17(3): 256-268.

Bruni, A., Gherardi, S. and Poggio, B. (2005). Gender and Entrepreneurship: An Ethnographic Approach. London: Routledge.

Butler, J. (1993). Bodies that matter: On the Discursive Limits of Sex. New York: Routledge.

Butler, J. (2004). Undoing Gender. London: Routledge.

Calás, M. and Smircich, L. (1992), Rewriting gender into organizational theorising: Directions from feminist perspective. In M. Reed and M. Hughes (Eds.), Rethinking Organizations, pp227253, London: Sage.

Calás, M., Smircich, L. and Bourne, K.A. (2009). Extending the Boundaries: Reframing "Entrepreneurship as Social Change" Through Feminist Perspectives. The Academy of Management Review, 34(4): 552-569.

Clegg, S. (2009) 'Doing Power Work'. In Buchanan, D. and Bryman, A., (Eds.) Sage Book of Organizational Research Methods. London: Sage.

Collins, O. F. and Moore, D. G. (1964) The Enterprising Man. East Lansing: Michigan State University.

Cornelissen, J., Clarke, J. and Cienki, C. (2012) Sense giving in entrepreneurial contexts: The use of metaphors in speech and gesture to gain and sustain support for novel business ventures. International Small Business Journal, 30(3): 213-231.

De Clercq, D. and Voronov, M. (2009). Toward a Practice Perspective of Entrepreneurship: Entrepreneurial Legitimacy as Habitus. International Small Business Journal, 27: 395-419.

Down, S. (2006). Narratives of Enterprise: Crafting Entrepreneurial Self Identity in a Small Firm. London: Edward Elgar.

Díaz García, C. and Welter, F. (2013). Gender identities and practices: Interpreting women entrepreneurs' narratives. International Small Business Journal 31(4): 384-403.

Duberley, J. and Carrigan, M. (2012). The career identities of 'mumpreneurs': Women's experiences of combining enterprise and motherhood. International Small Business Journal, DOI: $10.1177 / 0266242611435182$. 
Duberley, J. and Cohen L. (2010). Gendering Career Capital: An investigation of scientific careers. Journal of Vocational Behaviour, 76(1): 187-197.

Essers, C. and Benschop, Y. (2009). Muslim businesswomen doing boundary work: The negotiation of Islam, gender and ethnicity within entrepreneurial Contexts. Human Relations, 62(3): 403-423.

Fine, C. (2010). Delusions of Gender. London: Icon Books.

Gartner, W. (2010). A New Path to the Waterfall: A Narrative on a use of Narrative. International Small Business Journal, 28(1): 6-20.

Giddens, A. (1992). The Transformation of Intimacy. Cambridge: Polity Press.

Godwin, L., Stevens, C. and Brenner, N. (2006). Forced to play by the rules? Theorizing how mixed sex teams benefit women in male dominated contexts. Entrepreneurship Theory and Practice, 30(5): 623-642.

Golombisky, K. (2006). Gendering the interview: Feminist reflections on gender as performance in research. Women's Studies in Communication, 29: 165-192.

Greenman, A. (2012). Entrepreneurial activities and occupational boundary work during venture creation. International Small Business Journal, 30(2): 115-138.

Hackett, S.M. and Dilts, D.M. (2004). A Systematic Review of Business Incubation Literature. Journal of Technology Transfer, 29(1): 55-82.

Hancock, A. (2007). When Multiplication Doesn't Equal Quick Addition: Examining Intersectionality as a Research Paradigm. Perspectives on Politics 5(1): 63-79.

Heliman, M. (1983). Sex Bias in Work Settings: the Lack of Fit Model. Research in Organisational Behaviour, 5: 269-298.

Hogg, M.A. (2006). 'Social identity theory'. In P.J. Burke (Ed.), Contemporary social psychological theories (pp.111-136). Palo Alto, CA: Stanford University Press.

Hughes, K., Jennings, J., Brush, C., Carter, S and Welter, F. (2012) 'Extending Research in New Directions', Entrepreneurship Theory and Practice, 36(3): 429-442.

Hytti, U. and Maki, K. (2007). Which firms benefit most from the incubators? International Journal of Entrepreneurship and Innovation Management, 6: 506-23.

Ibarra, H. (1999). Provisional Selves: Experimenting with Image and Identity in Professional Adaptation. Administrative Science Quarterly, 44(6): 764-791.

Ibarra, H. and Barbulescu, R. (2010). Identity as Narrative: Prevalence, effectiveness and consequences of narrative identity work in macro work role transitions. Academy of Management Review, 35(1): 135-154.

Kelan, E.K. (2009). Gender fatigue: The ideological dilemma of gender neutrality and discrimination in organizations. Canadian Journal of Administrative Sciences, 26(3): 197-210.

Kelan, E.K. (2010). Gender logic and (un)doing gender at work. Gender, Work and Organization, 17(2): 174-194.

Kenny, K. (2010). Beyond ourselves: Passion and the dark side of identification in an ethical organization. Human Relations, 63(6): 857-875.

Kristeva, J. and Menke, L. (1989). Language: The Unknown: An Initiation Into Linguistics. New York, Columbia University Press.

Landstrom, C. (2007). Queering feminist technology studies. Feminist Theory, 8(7): 7-26.

Lewis, P. and Simpson R. (2010). Revealing and Concealing Gender. London: Palgrave.

Levi, J. (2006). Clothes Don't Make the Man (or Woman), But Gender Identity Might. Journal of Gender and Law, 15(1): 90-115.

Locke, K. (1996). A Funny Thing Happened? The Management of consumer emotions in service encounters. Organization Science, 7(1): 40-59. 
Lohan, M. and Faulkner, W. (2004). Masculinities and Technologies. Men and Masculinities, 6(4): 319- 329.

Lounsbury, M. and Glynn M.A. (2001). Cultural Entrepreneurship: Stories, Legitimacy and Acquisition of Resources. Strategic Management Journal, 22(3): 545-564.

Mac an ghaill, M. and Haywood C. (2007). Gender, culture and society. London: Palgrave.

MacNabb, A., McCoy, J., Weinreich, P. and Northover, M. (1993).Using Identity Structure Analysis (ISA) to Investigate Female Entrepreneurship. Entrepreneurship Regional Development, 5: 301-313.

McRobbie, A. (2009). The Aftermath of Feminism. London: Sage.

Marlow, S. and Patton, D. (2005). All credit to men? Entrepreneurship, finance and gender. Entrepreneurship, Theory and Practice, 29: 717-735.

Marlow, S. and McAdam, M. (2012). Analysing the influence of gender upon high technology venturing within the context of business incubation. Entrepreneurship, Theory and Practice, 36(4): 655-676.

Martin, J. (2000). Hidden Gendered Assumptions in Mainstream Organizational Theory and Research. Journal of Management Enquiry, 9(2):207-216.

Maxwell, J A. (2002). 'Understanding and validity in qualitative research'. In A. M. Huberman and M.B. Miles (Eds), The qualitative researcher's companion (pp.37-64). Thousand Oaks, CA: Sage.

McAdam, M. (2012) Female Entrepreneurship. Routledge: London.

Miles, M.B, and Huberman, A.M. (1994). Qualitative Data Analysis, pp. 10-12. Newbury Park, CA: Sage.

Neergaard H., Frederiksen S. and Marlow S. (2011). The Emperor's New Clothes: Rendering a feminist theory of entrepreneurship visible. Paper presented at the $56^{\text {th }}$ ICSB Conference, June Stockholm.

Ogbor, J. (2000). Mythicizing and reification in entrepreneurial discourse: Ideology critique of entrepreneurial studies. Journal of Management Studies, 35(5): 605- 630.

Patton, D. (2013). Realizing Potential: The Impact of Business Incubation upon the Absorptive Capacity of New Technology Based Firms. International Small Business Journal,

DOI: $10.1177 / 0266242613482134$.

Pratt, M. (2009). For the Lack of a Boilerplate: Tips on Writing up (And Reviewing) Qualitative Research. Academy of Management Journal, 52(5): 856-862.

Radu, M. and Redien-Collot, R. (2008). The Social Representation of Entrepreneurs in the French Press Desirable and Feasible Models? International Small Business Journal, 26(3): 259298.

Rice, M.P. (2002). Co-production of Business Assistance in Business Incubators: An Exploratory Study. Journal of Business Venturing, 17: 163-187.

Rindova, V., Barry, D. and Ketchen, D. (2009). Entrepreneurship as Emancipation. Academy of Management Review, 34(3): 477- 491.

Scillitoe, J.L. and Chakrabarti A.K. (2010). The role of incubator interactions in assisting new ventures. Technovation 30: 155-167.

Servon, L. and Visser, M. (2011). Progress hindered: the retention and advancement of women in science, engineering and technology careers. Human Resource Management Journal, 21(3): 272- 284.

Shaw, I.F. (1999). Qualitative Evaluation. London: Sage Publications. 
Shire, K., (2009). 'Gender and the conceptualisation of the knowledge economy'. In Walby, M., Gottfried, H., Gottshall, K. and Osawa, M. (Eds) Gendering the Knowledge Economy, pp5179. London: Palgrave.

Sigglekow, N. (2007). Persuasion with case studies. Academy of Management Journal, 50(1): 20- 24.

Sillince, J. and Barker, J. (2012). A Tropological Theory of Institutionalization. Organization Studies, 33(1): 7-38.

Smith, R. and Anderson, A.R. (2004). The Devil is in the E-tail: forms and structures in the entrepreneurial narratives. In Hjorth, D. and Steyaert, C. (Eds) Narrative and Discursive Approaches in Entrepreneurship (pp.125-143). Cheltenham: Edward Elgar.

Smith J.A. and Eatough, V. (2006). "Interpretative phenomenological analysis". In G. Breakwell, C. Fife-Schaw, S. Hammond and J. A. Smith (Eds.) Research Methods in Psychology (3rd Ed), pp.11-20. London: Sage.

Storey, D .and Greene, F. (2010). Small Business and Entrepreneurship. London: Pearson. Strauss, A. and Corbin, J. (1998). Basics of Qualitative Research. Thousand Oaks, CA: Sage.

Suls, J., Martin, R. and Wheeler, L. (2002). Social Comparison: Why, with whom and with what effect? Current Directions in Psychological Science, 11(5): 159-163.

Sveningsson, S.F. and Alvesson, M. (2003). Managing managerial identities: Organizational fragmentation, discourse and identity struggle. Human Relations, 56(10): 1163-1193.

Tornikoski, E. and Newbert, S. (2007). Exploring the determinants of organizational emergence: A legitimacy perspective. Journal of Business Venturing, 22(2): 311-335.

Tyler, M. and Cohen, L. (2010). Spaces that Matter: Gender Performativity and Organizational Space. Organization Studies, 31(2): 175-198.

Walby, Gottfried, H., Gottshall, K. and Osawa, M. (2009) Gendering the Knowledge Economy, London: Palgrave.

Wajcman, J. (2004). Technofeminism. Cambridge: Polity Press.

Watson, T.J. (2009). Narrative, Life Story and Manager Identity: A Case Study in Autobiographical Identity Work. Human Relations, 62(3): 425-52.

Watson, T.J. (2011). Ethnography, reality and truth: the vital need for students of 'how things work' in organisations and management. Journal of Management Studies, 8(1): 202- 216.

Watson, T.J., (2013). Entrepreneurship in action: Bringing together the individual, organisational and institutional dimensions of entrepreneurial action. Entrepreneurship and Regional Development, Forthcoming.

Watts, J.H. (2007). Porn, Pride and Pessimism: experiences of Women Working in Professional Construction Roles. Work, Employment and Society, 21(2): 299-316.

Woodfield, R. (2000). Women, Work and Computing. Cambridge: Cambridge University Press. Wry T., Lounsbury, M. and Glynn M.A. (2011). Legitimating Nascent Collective Identities: Coordinating Cultural Entrepreneurship. Organization Science, 22(2): 449-463.

Wynarczyk, P. and Marlow, S. (2010) (Eds) Innovating Women. London: Emerald.

Wynarczyk, P. and Renner, C. (2006). The 'Gender Gap' in the Scientific; Labour Market: The Case of Science, Engineering and Technology-Based SMEs in the UK. Equal Opportunities International, 25(8): 660-673.

Ybema, S., Keenoy T., Oswick C., Beverungen, A., Ellis, N. and Sabelis, I. (2009). Articulating Identities. Human Relations, 62(3): 299-322.

Table 1: Characteristics of Respondents 


\begin{tabular}{|l|l|l|l|l|}
\hline & Kath & Kim & Prue & Sharon \\
\hline Age & 41yrs & 43yrs & 42yrs & 40yrs \\
\hline Qualifications & $\begin{array}{l}\text { BSc (Hons) } \\
\text { Information } \\
\text { Technology }\end{array}$ & Arts Degree & $\begin{array}{l}\text { BSc (Hons) } \\
\text { Information } \\
\text { Technology }\end{array}$ & $\begin{array}{l}\text { BA } \\
\text { Business Studies }\end{array}$ \\
\hline $\begin{array}{l}\text { Main } \\
\text { product/service }\end{array}$ & $\begin{array}{l}\text { Implementation } \\
\text { of effective } \\
\text { vendor } \\
\text { management } \\
\text { strategies with } \\
\text { task-oriented } \\
\text { tools an international } \\
\text { techniques and }\end{array}$ & $\begin{array}{l}\text { product } \\
\text { exchange and } \\
\text { image } \\
\text { repository } \\
\text { service } \\
\text { manufacturing } \\
\text { optimization }\end{array}$ & $\begin{array}{l}\text { Provision of } \\
\text { innovative, } \\
\text { complete } \\
\text { technology } \\
\text { solutions for } \\
\text { public and } \\
\text { private sectors }\end{array}$ \\
\hline Incubator Status & 12 months & 16months & 18 months & 10months \\
\hline
\end{tabular}


Table 2: Stages of the Data Analysis Process

\begin{tabular}{|c|c|c|}
\hline Process of Analysis & Level of Analysis & Description of Analysis \\
\hline $\begin{array}{l}\text { 1. Familiarization with } \\
\text { content and initial } \\
\text { insight into data }\end{array}$ & Read for content & $\begin{array}{l}\text { The first stage involved } \\
\text { reading and then re -reading } \\
\text { of each case in order to } \\
\text { familiarize ourselves with } \\
\text { the material. }\end{array}$ \\
\hline 2. Immersion & $\begin{array}{l}\text { Comprehend and manage } \\
\text { data }\end{array}$ & $\begin{array}{l}\text { The second stage involved } \\
\text { the identification of broad } \\
\text { categories of themes } \\
\text { through a process of open- } \\
\text { coding (Strauss and Corbin, } \\
\text { 1998). Each transcript was } \\
\text { then coded which resulted in } \\
\text { relevant segments of texts } \\
\text { highlighted and then } \\
\text { organized into relevant } \\
\text { clusters. }\end{array}$ \\
\hline 3. Categorization & $\begin{array}{l}\text { Identifications of key } \\
\text { themes }\end{array}$ & $\begin{array}{l}\text { In the third stage, emergent } \\
\text { themes were developed in } \\
\text { order to develop tentative } \\
\text { links between the } \\
\text { transcripts in terms of } \\
\text { identity work, legitimacy, } \\
\text { gender and } \\
\text { entrepreneurship and } \\
\text { business incubation. }\end{array}$ \\
\hline $\begin{array}{l}\text { 4. Association and pattern } \\
\text { recognition }\end{array}$ & $\begin{array}{l}\text { Constant comparison } \\
\text { analysis }\end{array}$ & $\begin{array}{l}\text { Next, we integrated related } \\
\text { data drawn from the } \\
\text { different transcripts. This } \\
\text { strategy involved taking one } \\
\text { piece of data and comparing } \\
\text { it with all others that may be } \\
\text { similar or different in order } \\
\text { to develop } \\
\text { conceptualizations of the } \\
\text { possible relations between } \\
\text { various pieces of data (Miles } \\
\text { and Huberman, 1994). }\end{array}$ \\
\hline $\begin{array}{l}\text { 5. Interpretation and } \\
\text { representation }\end{array}$ & Writing up of data & $\begin{array}{l}\text { This writing-up stage } \\
\text { involved a "narrative } \\
\text { account of the interplay } \\
\text { between the interpretative } \\
\text { activity of the researchers } \\
\text { and participant's account of } \\
\text { her experience in her own }\end{array}$ \\
\hline
\end{tabular}




\begin{tabular}{|c|c|c|}
\hline & & $\begin{array}{l}\text { words" (Smith and Eatough, } \\
\text { 2006: 18). } \\
\text { In terms of our key research } \\
\text { question, three critical } \\
\text { themes emerged with } \\
\text { related sub-themes: 1: } \\
\text { identity and identity work 2: } \\
\text { business incubation 3: dress } \\
\text { and space. The subsequent } \\
\text { outcomes identified the core } \\
\text { meaning of the data, } \\
\text { remaining faithful to the } \\
\text { perspectives of the } \\
\text { respondents but within } \\
\text { wider social and theoretical } \\
\text { constructs (Shaw, 1999) }\end{array}$ \\
\hline $\begin{array}{l}\text { 6. Explanation and } \\
\text { abstraction }\end{array}$ & $\begin{array}{l}\text { Contribution to theory } \\
\text { development }\end{array}$ & $\begin{array}{l}\text { The final stage involved } \\
\text { recontextualising, or putting } \\
\text { the new knowledge about } \\
\text { the phenomena and } \\
\text { relations back into the } \\
\text { context of how others have } \\
\text { articulated the evolving } \\
\text { knowledge. This process also } \\
\text { identified new research } \\
\text { avenues and potential } \\
\text { interesting questions of } \\
\text { further inquiry. }\end{array}$ \\
\hline
\end{tabular}


Table 3: Mapping of Themes in the Data onto Stories within the Literature

\begin{tabular}{|c|c|c|c|c|c|}
\hline Gender issues & Career & Performance & Dress Codes & $\begin{array}{l}\text { Other gender } \\
\text { Issues }\end{array}$ & Mentoring \\
\hline Gender & $\begin{array}{l}\text { We need a } \\
\text { girl to chat } \\
\text { up the } \\
\text { clients. } \\
\text { All women } \\
\text { had to take } \\
\text { a typing } \\
\text { test. } \\
\text { It is tricky } \\
\text { being a } \\
\text { female in } \\
\text { ICT. }\end{array}$ & $\begin{array}{l}\text { If it goes } \\
\text { wrong, it } \\
\text { would be me } \\
\text { that failed as } \\
\text { well } \\
\text { (identifying } \\
\text { with the } \\
\text { business). } \\
\text { Game } \\
\text { playing. }\end{array}$ & $\begin{array}{l}\text { Not losing sight } \\
\text { of being } \\
\text { female. }\end{array}$ & $\begin{array}{l}\text { Men cannot } \\
\text { help } \\
\text { themselves. } \\
\text { Visibly stand } \\
\text { out. }\end{array}$ & $\begin{array}{l}\text { Learning } \\
\text { how to } \\
\text { 'think } \\
\text { properly, to } \\
\text { think like a } \\
\text { man'. } \\
\text { Feeling } \\
\text { versus } \\
\text { strategizing. }\end{array}$ \\
\hline Legitimacy & $\begin{array}{l}\text { A chance to } \\
\text { prove } \\
\text { oneself. } \\
\text { Partner } \\
\text { with men } \\
\text { (to achieve } \\
\text { osmotic } \\
\text { credibility). }\end{array}$ & $\begin{array}{l}\text { It was } \\
\text { assumed } \\
\text { women } \\
\text { would be } \\
\text { lightweights } \\
\text { so the } \\
\text { women } \\
\text { worked } \\
\text { 17hrs a day - } \\
\text { a lot of } \\
\text { harder than } \\
\text { most of the } \\
\text { blokes. }\end{array}$ & $\begin{array}{l}\text { Looks } \\
\text { professional - } \\
\text { blend in } \\
\text { Find the } \\
\text { medium } \\
\text { between } \\
\text { "smart tart" } \\
\text { and "plain } \\
\text { Jane". }\end{array}$ & $\begin{array}{l}\text { Taking } \\
\text { advantage of } \\
\text { being women } \\
\text { i.e. feminine } \\
\text { wiles (to } \\
\text { achieve } \\
\text { something } \\
\text { from men). }\end{array}$ & $\begin{array}{l}\text { Male } \\
\text { mentors } \\
\text { provided a } \\
\text { legitimacy } \\
\text { premium. }\end{array}$ \\
\hline Entrepreneurship & $\begin{array}{l}\text { Autonomy. } \\
\text { Being one's } \\
\text { own boss } \\
\text { avoids } \\
\text { chauvinism. }\end{array}$ & $\begin{array}{l}\text { They took } \\
\text { kindly to } \\
\text { me.... maybe } \\
\text { something } \\
\text { to do with } \\
\text { being a girl. } \\
\text { Women are } \\
\text { a novelty. }\end{array}$ & $\begin{array}{l}\text { Techno } \\
\text { entrepreneurs' } \\
\text { attire can be bit } \\
\text { eccentric or } \\
\text { unconventional. }\end{array}$ & $\begin{array}{l}\text { Tenancy } \\
\text { application } \\
\text { consideration } \\
\text { not on merit } \\
\text { alone. }\end{array}$ & $\begin{array}{l}\text { Male } \\
\text { mentor was } \\
\text { a given. } \\
\text { Given the } \\
\text { choice the } \\
\text { women } \\
\text { would } \\
\text { chose a } \\
\text { male } \\
\text { mentor. }\end{array}$ \\
\hline
\end{tabular}


Appendix One: Additional fragments of the narrative accounts shared by the respondents in relation to three critical themes and related sub-themes:

\begin{tabular}{|c|c|c|}
\hline Theme & Enacted as... & Interview Excerpts \\
\hline $\begin{array}{l}\text { identity \& } \\
\text { identity work }\end{array}$ & $\begin{array}{l}\text { a gendered } \\
\text { performance in } \\
\text { the context of } \\
\text { technology } \\
\text { entrepreneurship }\end{array}$ & $\begin{array}{l}\text { 'Not long before I left, I went for a senior job and was asked to take a typing } \\
\text { test; I cannot imagine them asking a man to do that but no one, not even } \\
\text { the HR people, found it strange?' (Kath) } \\
\text { 'If you want to survive in the industry, I guess you have to be a particular } \\
\text { type of person, you need to be bullish, you have to push your way through; } \\
\text { there was no room for shrinking violets where I worked' (Prue) } \\
\text { 'I kept my head down; I also worked three times as hard as the blokes so } \\
\text { they could never accuse me of not being just as good' (Sharon) } \\
\text { 'ICT is largely male dominated and I just wasn't making headway; it gets } \\
\text { tough always having to be one of the boys' (Kim) } \\
\text { 'Only now I look back and think of all the times I sort of deferred to the } \\
\text { others [qualified specifically as male colleagues] or found what I thought } \\
\text { were tactful ways of getting my point across as I didn't want to look too } \\
\text { pushy' (Prue) } \\
\text { 'If you want to succeed, you have to be prepared to change to fit in- so go } \\
\text { with the flow really but it really is a boys world but I just got on with it; } \\
\text { what else can you do' (Sharon) } \\
\text { 'When I was working in the corporate world I relentlessly chased down } \\
\text { contracts; it nearly killed me and now I think I was just trying to make a } \\
\text { point about being as good as my male colleagues as I was the only woman } \\
\text { but I remember one bloke telling me it was just my pretty face that got the } \\
\text { deal- what can you say to that' (Kim) }\end{array}$ \\
\hline $\begin{array}{l}\text { Business } \\
\text { Incubation }\end{array}$ & $\begin{array}{l}\text { a legitimising } \\
\text { device }\end{array}$ & $\begin{array}{l}\text { 'I'm in an environment (the incubator) where its mostly men and even } \\
\text { funnier than that they are all younger than me' (Kath) } \\
\text { 'Coming in here was a not a male or female choice, it was a business } \\
\text { decision. It wasn't until I got in here that I realised that I was in the } \\
\text { minority' (Sharon) } \\
\text { 'Women have an innate sense of wanting to be protected... but you're not } \\
\text { going to be protected when you come in here given the competition but } \\
\text { my mentor is great in that respect, he looks after me' (Kim) } \\
\text { 'To get on, I think you have to be a hunter, you have to learn not to be } \\
\text { emotional and girly-just get on and do it' (Kath) } \\
\text { 'I learned a lot by default, just listening quietly as I know if I asked a } \\
\text { question, the flow of the conversation would change: I would be noticed } \\
\text { and everything changed-you get asked how your kids are, not what your } \\
\text { finance strategy is' (Sharon) } \\
\text { 'You need to play the game, there's a whole lot of subtle stuff happening I } \\
\text { would not see. My mentor- he knows the right rules and he can interpret } \\
\text { all that stuff but the best thing is, if he comes out in my corner, I get taken } \\
\text { more seriously as to be honest, there is an assumption I am either the } \\
\text { receptionist or secretary' (Kim) }\end{array}$ \\
\hline
\end{tabular}




\begin{tabular}{|l|l|l|}
\hline Dress and & $\begin{array}{l}\text { Coded } \\
\text { interpretations of } \\
\text { fit }\end{array}$ & $\begin{array}{l}\text { 'I spent many years wearing trousers and being, trying to be one of the } \\
\text { boys and I think as I've got a bit older and I've matured in my own sense } \\
\text { and belief in my own abilities I've decided that I can dress a bit more girly } \\
\text { and get away with it' (Prue) } \\
\text { 'Well, techy entrepreneurs are supposed to be a bit eccentric - it's } \\
\text { supposed to be nerdy and odd so they [men] can get away with it, I don't } \\
\text { think we can so much, sorry to keep returning to this, but it is about being } \\
\text { taken seriously and I do think that is different for men and women' } \\
\text { (Sharon) } \\
\text { 'It's bad enough that you are the only women in the room, so you don't } \\
\text { want what you are wearing to be the point of attention as it just takes } \\
\text { away from the point you are trying to get across - it's all part of a very } \\
\text { carefully crafted image really' (Sharon) } \\
\text { 'I was in an meeting one time with a potential investor who said "I like your } \\
\text { shoes' - at that point I felt he obviously wasn't really interested in what I } \\
\text { had to say or perhaps he thought he was being kind because that's what } \\
\text { 'we girls' like to hear' (Kim) } \\
\text { 'The incubator is very modern, but all this open space and glass makes you } \\
\text { feel that you are in goldfish bowl, it is not really a very welcoming place' } \\
\text { (Prue) } \\
\text { 'The environment is stereotypically 'techno' in being all hard and straight } \\
\text { lines; it makes a good image for the business but you have to learn how to } \\
\text { fit with it; mark you, however you try and fit it doesn't always work, if I } \\
\text { meet someone wondering lost around reception, they always ask me for } \\
\text { help as they have me down as the receptionist' (Kath) }\end{array}$ \\
\hline
\end{tabular}

